\title{
KEPEMIMPINAN VISIONER
}

\section{(Studi Multi Kasus di SD Unggulan Al-Ya'lu Malang dan SD I Alam Bilingual Surya Buana Malang)}

\author{
Muh. Hambali \\ Dosen Fakultas Tarbiyah UIN Maulana Malik Ibrahim Malang
}

\begin{abstract}
Visioner Leadership is formulate, transform, perform, and actuate ideal opinions from their self and social interaction between school citizen and stakeholder as school idea in the next period. Whereas, the goal of qualitative research with multicases characteristicto describe visioner leadership characteristic in "SD UnggulanAl-Ya'lu Malang dan SDI Alam Bilingual Surya Buana Malang", describe visioner leadhership, develop visioner soul, and comparation of two institute. This research explain, that visioner leadership characteristic of two institute this, have integrity soul, adaptation soul, direction determining, positive thinking, dicipline, competition tradition. Two modals in elementary school to improve leadership soul based on personifacation of visi and leadership head master referency, values, and believing, reward, and ripeness of teacher emotion, self evaluation, and arrange development planning of human resoucess. Whereas, visionelization leadership emphasize the different superiority one each other. Leadership is strengthen superiority tradition for school citizen. History prove school dispersion caused leadership fading which not strengthen perspective that become point of institute development.
\end{abstract}

Keyword: Leadership and Visionary

\section{A. Pendahuluan}

Kepemimpinan yang memiliki visi adalah dapat mengorganisasi suatu kelemahan lembaga menjadi kekuatan dan mengorganisasi tantangan lembaga menjadi peluang untuk mencapai cita-cita bersama sekolah. Organisasi sekolah mencerminkan gabungan individu yang terdiri-dari dua orang atau lebih yang berkumpul dalam setiap kelompok untuk mewujudkan visi. Tugas kepemimpinan adalah mewujudkan harapan-harapan visi sekolah dan untuk mengerjakan tujuan bersama (Gary Yukl, 1981: 7). Oleh sebab itu, kepemimpinan adalah menetapkan arah yang dapat dirasakan (a sensible direction), membuat orang-orang menyelaraskan diri ke arah itu, dan memberi mereka kekuatan (energizing them) untuk mencapainya dengan cara-cara yang terencana (John P. Kotter, 1994). 
Kepemimpinan yang memiliki visi atau dapat disebut kepemimpinan visioner, terdiri dari dua kata, yaitu kepemimpinan dan visioner. Kepemimpinan adalah mempengaruhi orang lain dan membangun inovasi-inovasi secara langsung di dalam organisasi (R.M. Steers, G.R. Ungson, R.T. Mowday, 1985: 3007). Senada pendapat Kasali bahwa pemimpin mesti dapat menjadi motivator, coach, penerjemah, nabi, dai, guru, paus, jenderal, atau panglima (Rhenald Kasali, 2007: 128).

Sedangkan visioner adalah orang yang memiliki wawasan ke depan (Depdiknas, 2005: 1262). Visioner berusaha mengambarkan sesuatu hal berbasis ke masa depan dan berusaha menunjukkan kekuatan untuk bertahan ketika mengalami kemunduran atau kegagalan (Warren Bennis, 1994: 39). Visioner juga mengkontruksi perubahan-perubahan yang dinamis, lebih memikirkan pada manfaat, nilai dan tanggung jawab. Visioner menunjukkan sifatnya terbuka dan melihat pada potensipotensi yang mungkin terjadi tanpa mempunyai kepastian mengenai hasil-hasilnya. Masa depan adalah masa kini yang sedang diarahkan oleh manusia itu sendiri (HAR Tilaar, 1997: 82). Visi masa depan ini harus dimiliki oleh setiap pemimpin sekolah. Pertama, dalam kaitan ini visi masa depan memberikan wawasan makro yang dapat dijadikan dasar bertindak bagi para pemimpin (HAR Tilaar, 1997: 34). Kedua, daya pikir memiliki kekuatan yang luas dan dapat menerobos batas-batas fisik, waktu dan tempat.

Menurut Beach bahwa bervisi tidak dibatasi hanya investigasi secara alamiah, tetapi menginspirasi kejiwaan, fantasi, dan intuisi, memberanikan penjelasan, sasaran, dan memperkuat keyakinan terhadap sasaran yang dicapai. Visioner merupakan masa depan yang ideal, dapat berupa budaya dan kegiatan organisasi yang sedang berjalan (Lea Roy Beach, 1993: 50).

Senada pendapat Robbins yang menyatakan kepemimpinan visioner yaitu (Stephen Robbins, 1996: 375);

Visionary leadership is the ability to create and articulate a realistic, credible, attractive vision of the future for an organization or organizational unit that grows out of and improves upon the present.

Pendapat tersebut menggambarkan keteguhan kepemimpinan visioner mengelola organisasi yang membangun harapan ke depan. Keteguhan kepemimpinan adalah adanya karakteristik integritas. Integritas mengandung unsur terbuka, jujur, 
toleran, percaya diri, peduli, dan komitmen pada tradisi masa lalu yang terbaik (Burt Nanus, 1989: 81-87). Integritas adalah konsistensi antara nilai dan tindakan. Pemimpin yang memiliki integritas sejalan dengan nilai-nilai prinsipnya. Integritas pemimpin ditandai dari cara membangun komitmen kepada para guru dan para pegawai dalam mencapai kemampuan prestasi warga sekolah untuk memiliki unggulan dan mempengaruhi persepsi masyarakat (Gary Yukl, 1981: 9).

Karakteristik integritas melahirkan kekuatan dan adaptasi pribadi pemimpin. Semangat ini membangun sifat-sifat baik yang sesuai dengan nilai dan keyakinan yang dianut (Tobroni, 140). Dengan memiliki integritas, seorang pemimpin akan tampil apa adanya pada diri sendiri dan orang lain, mampu tampil dengan percaya diri dan tanpa beban, mampu menjalin hubungan sejati dengan orang lain, dapat dipercaya dan mempercayai, merasakan kenyamanan dan kedamaian dalam dirinya.

Sejalan dengan karakteristik integritas adalah memiliki semangat beradaptasi terhadap tuntutan pendidikan. Karakteristik ini adalah kemampuan pemimpin berinisiatif menangkap hambatan menjadi peluang (Burt Nanus, 1989: 81-87). Kemampuan ini mempengaruhi referensi pengalaman dan pengabdian yang tinggi. Pengalaman tersebut memiliki nilai dan filosofi yang mempengaruhi cara pandang dan sikap dalam mencapai kemajuan sekolah. Selain itu, pengalaman seseorang pemimpin berdasarkan cara menghargai emosi sendiri dan orang lain, mengatur emosi sendiri dan orang lain, dan menggunakan emosi sendiri secara adaptif (M. Syafii Antonio, 2007: 27). Tiga kecakapan emosi memandu mengembangkan lembaga secara efektif.

Karakteristik pemimpin tersebut di atas dijiwai oleh nilai, harapan, gagasan dan partisipasi stakeholder dari pada kepentingan yang bersifat nampak (Gary Yukl, 1981: 283). Kepemimpinan visioner adalah memfokuskan diri pada masalah-masalah yang bernilai tinggi, yaitus berkarnya dan berinovasi di sekolah. Untuk menunjangnya adalah adanya standar ideal yang dapat menggambarkan masa depan sekolah. Standar ideal itu adalah suatu kepemimpinan yang memiliki visi. Tidak ada kepemimpinan tanpa adanya visioner (Richard L. Hughes, Robert C. Ginrett, Gordon J. Curphy, 2002: 390).

Berdasarkan uraian di atas, maka nampak kepemimpinan visioner terjadi di Sekolah Dasar Unggulan Al-Ya'lu di Malang. Fenomenanya adalah pemimpin sering mengungkap kalimat menjadi sekolah unggulan dari yang sudah unggul kepada 
setiap guru dan pegawai. Kalimat itu diadaptasi dari visi SD yang berasal dari visi sekolah "menjadi lembaga pendidikan yang unggul di era global". Visi Keunggulan itu mampu menjiwai seluruh warga sekolah, namun kepala sekolah selaku pemimpin menginternalisasi dalam diri terlebih dahulu dan menunjukkan keunggulankeunggulan dalam bentuk prestasi guru. Kepemimpinan memperoleh hasil sesuai visi manakala memulainya dari keteladan. Hal dikuatkan dari nilai-nilai keteladan yang pernah tersurat dalam sejarah hijrah Nabi Muhammad SAW (Muhammad Syafii Antonio, 2007: 67).

Pemimpin sekolah juga menunjukkan tradisi kedisiplinan, wajah penampilan pendidik yang profesional, wajah penampilan pegawai administrasi yang profesional. Keunggulan tersebut berimplikasi kepada keberhasilan prestasi guru dan prestasi siswa baik di tingkat lokal maupun nasional. Prestasinya sekolah ditunjukkan pemimpin sekolah melalui personal computer (PC) miliknya yang sudah tersambung dengan jaringan internet sekolah secara on line dan membuka website SD Al-Ya'lu. Salah satu yang ditunjukkan kepala sekolah adalah internalisasi nilai-nilai keteladanan selaku guru yang berusaha menunjukkan keunggulan dalam membuat karya-karya ilmiah berupa buku ajar. Buku ajar yang telah mendapatkan katagori terbaik dari Pusat Perbukuan Nasional di Jakarta. Buku lainnya adalah buku pengkayaan untuk menunjang mata pelajaran pendidikan kewarganegaraan kelas II mendapatkan juara tiga tingkat nasional dari Pusat Perbukuan Nasional di Jakarta pada November 2009.

Oleh karena itu, kepercayaan masyarakat mengalami peningkatan untuk mendaftarkan peserta didik di SD Unggulan Al-Ya'lu Malang meskipun di SD Unggulan Al-Ya'lu relatif muda berdirinya. Pendaftar di SD tersebut adalah enam puluh siswa yang terbagi menjadi tiga kelas yang setiap kelas berjumlah dua puluh siswa. Perubahan peningkatan jumlah dari sembilan siswa menjadi enam puluh siswa adalah kepercayaan yang telah diberikan masyarakat. Keberhasilan tersebut merupakan kontribusi kepemimpinan sekolah yang dapat menggerakkan warga sekolah. Sekolah ini merupakan peserta baru dalam ujian nasional telah menunjukkan perkembangan nilai rata-rata terbaik di Kota Malang pada tahun 2009.

Sekolah lainnya adalah SDI Alam Bilingual Surya Buana Malang. Sekolah ini merupakan unit pendidikan bercirikan Islam, dwibahasa (bilingual), dan sekolah alam. Kepala sekolah SDI ini pernah mengelola lembaga pendidikan MIN, MTsN, dan MAN di jalan Bandung Kota Malang. Kepala sekolah telah memberikan ciri dwi bahasa 
(bilingual) dan bercirikan alam di dalam nama sekolah Surya Buana. Kata alam diartikulasikan dalam konsep belajar tripel R. Pertama, reasoning mempunyai makna berpikir dasar, kritis, dan kreatif. Kedua, research mempunyai makna menangkap gejala, memprediksi, membuktikan, menyimpulkan, dan mengembangkan. Ketiga, religious mempunyai makna tadhabur, mengagumi ciptaan Illahi, dan meningkatkan keimanan. Pendekatan belajar metode triple $\mathrm{R}$ menjadi model pembelajaran yang menekankan di luar kelas. Kepala sekolah mendorong para guru menggunakan alam sekitar menjadi sarana pembelajaran.

Karakteristik sekolah tidak lepas dari kepemimpinan yang memiliki visi. Visinya adalah unggul dalam prestasi, terdepan dalam inovasi, dan maju dalam kreasi untuk membentuk insan berakhlakul karimah. Visi ini menginspirasi warga sekolah untuk berusaha terus-menerus dalam mengembangkan tradisi-tradisi unggulan sekolah . Pemimpin sekolah mempengaruhi guru untuk menjiwai visi unggul dalam menjalankan aktivitas pembelajaran di kelas. Hal itu telah ditunjukkan seorang guru kelas dalam membuat alat peraga pembelajaran yang mendapatkan prestasi juara I tingkat nasional yang diselenggarakan oleh PT Kraf Biskuit bekerjasama dengan pendidikan nasional pusat Jakarta tahun 2008.

Senada dengan pendapat Kenneth Blanchard. Pendapatnya adalah The key successful leadership today is influence, not authority. Pendapat tersebut dikutip oleh Kasali. Pendapatnya adalah kepemimpinan ditandai oleh kemampuan kepala sekolah melakukan perubahan peningkatan mutu lembaga berdasarkan cara mempengaruhi persepsi masyarakat (Rhenald Kasali, 2007: 17). Sebagaimana juga kepemimpinan adalah kemampuan pemimpin mempengaruhi dan menggerakkan sebuah kelompok untuk mencapai tujuan organisasi (Stephen Robbins, 347).

Tujuan organisasi dipengaruhi oleh sebuah nilai. Menuru Quilet bahwa nilai merupakan keyakinan yang mendasar dalam organisasi (Joseph V. Quiqley, 1993: 86). Nilai itu mempunyai pengaruh pada seorang pemimpin dalam menggerakkan organisasi, nilai itu mengenai apa yang sebenarnya dipengaruhi oleh nilai, dan nilai itu mempunyai pengertian adanya tata tingkat preferensi nilai terhadap modul perilaku kepemimpinan. Nilai mempunyai fungsi sebagai penggerak aktivitas masyarakat dan menjiwai semangat mewakafkan diri ke lembaga. Nilai-nilai organisasi merupakan prinsip operasional dan arahan untuk mencapai visi dan misi organisasi yang mampu mengekpresikan keyakinan dan aspirasi lembaga (Edward Sallis, 1993: 97). 
Misi adalah implementasi visi yang merupakan hasil pemikiran seseorang, pemimpin, dan lembaga yang meliputi pertanyaan, bersedia menjadi lembaga yang diharapkan oleh kepemimpinan yang tergambar dalam visi. Pemimpin sekolah menjalankan misi beserta dengan warga sekolah merupakan wujud mengawal visi dan misi agar sesuai dengan harapan bersama. Sedangkan tujuannya merupakan arah ke mana organisasi dibawa yang meliputi pertanyaan, bersedia menghasilkan apa, untuk siapa, dan keunggulan perlu ditunjukkan dari hasil tujuan pendidikan.

Kepemimpinan sekolah adalah menggerakkan sistem bersinergi dengan warga sekolah dalam memberikan keteladan, melakukan binaan, memberikan pelayanan yang menyenangkan baik kepada orang tua siswa dan siswa, mengevaluasi semua ruangan sekolah, dan mengevaluasi kebutuhan apa yang belum terpenuhi. Pemimpin tidak hanya membuktikan keunggulannya, misalnya, kemampuan membaca AlQur'an, kemampuan bahasa asing aktif dalam bentuk debat dan pidato, tradisi menulis karya ilmiah, dan ketrampilan dalam mempraktekkan ibadah wajib dan sunnah. Sekolah tersebut juga harus membuktikan hasil ujian nasional yang terbaik kepada masyarakat.

Berdasarkan fenomena di atas sekolah SD Unggulan Al-Ya'lu dan SDI Alam Bilingual Surya Buana menunjukkan kepemimpinan visioner. Kepemimpinan visioner sangat dibutuhkan di sekolah yang sedang membangun kepercayaan ke publik tentang sekolah yang memiliki jiwa inovasi dan jiwa adaptasi. Pemimpin sekolah menjiwai nilai-nilai itu berdampak perbuatan kebaikan dan kerja-kerja kolektif yang didorong oleh nilai agama. Hal ini juga adalah seorang pemimpin merupakan jiwa atau nilai yang menyebabkan adanya personifikasi kepemimpinan. Pesan tersirat dalam Al-Qu'an surat Al-'Ashr, ayat 3".

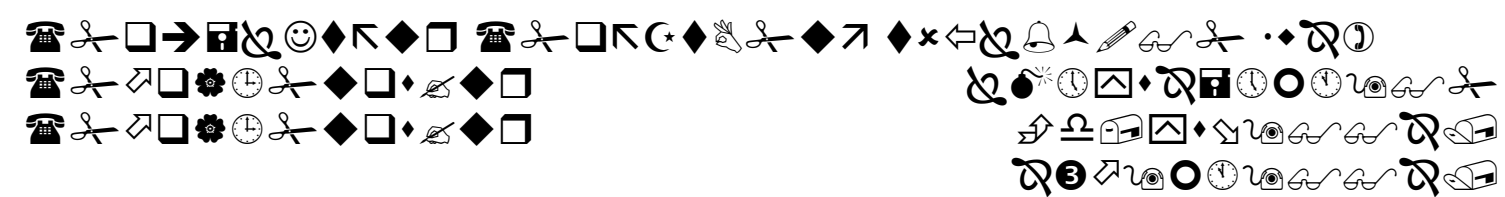

Artinya : "Kecuali orang-orang yang beriman dan mengerjakan amal saleh dan nasehat menasehati supaya mentaati kebenaran dan nasehat menasehati supaya menetapi kesabaran."

Hal ini juga merujuk hadis Nabi Muhammad SAW. yang artinya setiap kalian adalah pemimpin, dan setiap pemimpin bertanggungjawab terhadap kepemimpinannya. Senada pendapat Antonio bahwa kepemimpinan membutuhkan 
kesungguhan diri dan integritas diri yang menekankan kemampuan pengelolaan diri. Seorang pemimpin yang mampu mengelola dirinya berarti dapat mengelola lembaga.

Kepemimpinan diri mempunyai makna menegakkan disiplin atas diri pribadi (self discipline.) Hal ini merupakan aktivitas yang paling berat karena berkaitan dengan diri sendiri dan tidak melibatkan orang lain. Kepemimpinan yang efektif sangat ditentukan oleh kualitas diri dalam mengelolanya. Kepemimpinan merupakan peristiwa sosialisasi diri dalam suatu organisasi. Suatu organisasi memiliki kekuatan dan kelemahan. Kepala sekolah bertugas memaksimalkan kekuatan yang dimiliki organisasi dalam menggerakkan sistem yang berlaku. Kepemimpinan organisasi sekolah akan mendapatkan koreksi dari orang lain jika berbuat salah (Muhammad Syafii Antonio, 2007: 68).

Dengan demikian, penulis mencermati kepemimpinan kepala yang mencakup kepala sekolah dan wakilnya, guru, dan pegawai mampu menggerakkan untuk mencapai harapan-harapan sekolah. Kepemimpinan visioner dibangun melalui integritas, kedisiplinan, dan keteladanan. Kepemimpinan yang dapat melakukan inovasi dan menghadapi tantangan pendidikan ke depan. Ini adalah model kepemimpinan kepala sekolah yang visioner. Untuk itu, persoalan ini sangat menarik untuk diteliti, karena dua lembaga sekolah ini berdirinya relatif baru dibanding dengan sekolah lain di Malang. Sebaliknya, dua lembaga pendidikan telah melakukan inovasi, budaya kompetisi, dan keunggulan sekolah.

\section{B. Pengertian Kepemimpinan}

Pemimpin memfokuskan pada kegiatan, perubahan, dan proses kelompok (Bernard M. Bass, 1981: 7). Pemimpin memiliki posisi khusus sebagai agen utama dalam menetapkan struktur, iklim, tujuan, ideologi, kegiatan kelompok, dan karakteristik budaya. Perubahan-perubahan organisasi pendidikan terjadi adanya kepemimpinan. Kepemimpinan merupakan kerja bersama-sama yang dilakukan oleh seluruh individu dalam organisasi yang berbasis sistem dan mekanisme kerja yang berlaku suatu organisasi.

Menurut Yukl definisi kepemimpinan kurang lebih ada sepuluh penjelasan sebagai berikut (Gary Yukl, 2002: 3). Namun peneliti menetapkan dua pendapatnya. Kepemimpinan adalah mengartikulasikan visi, mewujudkan nilai-nilai, dan meciptakan lingkungan kedalam suatu hal dapat berprestasi. Dan, kepemimpinan 
adalah kemampuan individu untuk mempengaruhi, motivasi, dapat memberikan kontribusi terhadap efektivitas dan mensukseskan organisasi.

Kepemimpinan mempunyai keragaman definisi. Salah satu menurut Stoner, kepemimpinan manajerial dapat didefinisikan sebagai suatu proses pengarahan dan pemberian pengaruh pada kegiatan-kegiatan dari sekelompok anggota yang saling berhubungan tugasnya. Ada tiga implikasi menyangkut definisi, yaitu pertama, kepemimpinan antara orang lain-bawahan. Kedua, kepemimpinan menyangkut suatu pembagian kekuasaan yang tidak seimbang di antara para pemimpin dan anggota kelompok. Ketiga, selain dapat memberikan pengarahan kepada bawahan, pemimpin dapat juga mempergunakan pengaruh.

Kepemimpinan dianjurkan bersifat autentik: jujur baik kepada individu dan kelompok. Agar dapat jujur kepada diri manusia, penulis perlu memperhatikan setiap ketidak-selarasan yang ada antara metafora yang penulis diakui dan perilaku yang dituntut oleh metafora itu. Jadi, jika isu yang dihadapi oleh rasisme, maka tantangan awal bagi kepemimpinan adalah mengandung supremacist untuk menjamin suatu tempat bagi semua, mengundang pembebas untuk memberdayakan partisipasi bagi semua, mengandung pelaku perjalanan untuk memperhatikan semua, mengandung pencipta untuk mengambil tanggung jawab atas semua (Robert W. Terry, 2002: 266).

Definisi kepemimpinan dapat ditarik kesimpulan bahwa masing-masing arti berbeda menurut sudut pandang penulisnya. Namun demikian, ada kesamaan dalam mendefinisikan kepemimpinan, yakni mengandung makna memengaruhi orang lain untuk berbuat seperti yang pemimpin kehendaki. Jadi, kepemimpinan adalah ilmu dan seni menggerakkan dan mempengaruhi organisasi untuk bertindak sesuai visi, misi, dan tujuan lembaga pendidikan. Senada pendapat William Cohen (William A. Cohen, 1990), kepemimpinan adalah seni mempengaruhi orang lain untuk melakukan unjuk kerja maksimum guna menyelesaikan suatu tugas, mencapai suatu tujuan atau menyelesaikan sebuah proyek.

Kepemimpinan yang menempatkan posisi seni dan ilmu untuk mempersuasi individu dan kelompok untuk mengikuti perintah-perintah pemimpin dalam sebuah organisasi pendidikan. Perintah pemimpin menjadi kerja kolektif dari lembaga yang memiliki ukuran tertentu dan sesuai target yang diharapkan. Hal ini menegaskan bahwa kepemimpinan merupakan kinerja kolektif dan mempunyai tujuan mulia yang menjalankan visi, misi, tujuan, dan nilai organisasi sekolah. 


\section{Pengertian Visioner}

Visioner yang sudah menjadi perbendaharaan dalam Kamus Besar Bahasa Indonesia yang berasal dari kata Inggris, yaitu vision atau visionary. Vision melekat pada ciri pemimpin. Vision menjadi visionary, a person given to fanciful speculations and enthusiasms with little regard for what is actually possible Category. Visionary mempunyai makna seseorang yang memiliki spekulasi yang fantatis dan kegairahan yang fantatis terhadap katagori tertentu yang mungkin dapat diwujudkannya.

Lembaga pendidikan akan mengalami perubahan-perubahan ke arah lebih baik dari sebelumnya jika pemimpin mengembangkan daya pikir besar, berorientasi ke depan, dan bersifat jangka panjang. Sebagaimana pemikiran Kasali bahwa visioner mempunyai arti berpikir besar dan baru (think big and new) dan berpikir imajinasi (Think imaginative) (Rhenald, 2007: 138). Ini artinya bahwa visioner menjelaskan, yaitu 1) kemampuan membuka pagar batas organisasi, agar lebih banyak jendela, 2) kemampuan memberi multi perspektif melalui perjalanan inspiratif, pencerahanpencerahan, 3) pelatihan-pelatihan terbuka, memberi ruang interaktif dengan dunia luar.

Visioner merupakan karakteristik pemimpin. Pemimpin yang reaktif adalah memiliki kecenderungan berpikir jangka pendek dalama mencapai tujuan. Ini artinya berlawanan dengan makna visioner. Pemimpin tanpa memiliki visioner adalah pemimpin yang reaktif. Pemimpin yang memiliki sifat reaktif berdampak bekerja cepat merespons semua tindakan, tetapi hasilnya tidak efektif. Ia hanya berorientasi pada segala hal yang kasat mata, yaitu di sini dan saat ini. Pemimpin yang visioner juga mengedepankan pengelolaan organisasi berdasarkan rencana-rencana yang bersifat baru dan dinamis, sebaliknya karakteristik manajer yang mengedepankan menjaga stabilitas kinerja organisasi. Sebagaimana yang dijelaskan tabel karakteristik pemimpin dan karakteristik manager berikut ini (Richard L. Hughes, 2002: 387).

Tabel

Karakteristik Pemimpin dan Karakteristik Manager

\begin{tabular}{|l|l|}
\hline \multicolumn{1}{|c|}{ Pemimpin } & \multicolumn{1}{c|}{ Manager } \\
\hline Vision & Plan \\
\hline Inspiratif & Reward \\
\hline Empower & Direct \\
\hline Coach & Train \\
\hline Revenues & Expenses \\
\hline Forecasts & Budgets \\
\hline Possibilities & Systems and Procedures \\
\hline
\end{tabular}




\begin{tabular}{|l|l|}
\hline Opportunity & Schedule \\
\hline Synergy & Coordinate \\
\hline
\end{tabular}

Bennis (W. Bennis \& R. Townsend, 1995: 6) membedakan karakteristik antara pemimpin dan manajer. Dua istilah tersebut akan lebih baik terintegrasi dalam kepemimpinan lembaga pendidikan. Lembaga pendidikan tidak hanya membutuhkan karakteristik pemimpin, lembaga pendidikan juga membutuhkan karakteristik manager. Menurutnya adalah:

"Leaders are people who do the right things and managers are people who do things right. Leaders are intersted in direction, vision, goals, objectives, intention, purpose, and effectiveness - the right thing. Managers are intersted in efeciency, the how - to, the day, to - day, the short run of doing things right".

Karakteristik pemimpin adalah memiliki visi yang mampu memandu dalam mengelola organisasi pendidikan secara terus-menerus. Visioner menghadirkan dunia makna mimpi masa depan yang perlu direspon agar impian-impian lembaga dapat diwujudkan. Visioner dapat memberikan inspirasi, menggugah emosi, membangkitkan antusiasme, dan menyuntikkan motivasi. Motivasi inidividu maupun kelompok dapat menimbulkan sense of direction, menunjukkan arah yang perlu ditempuh. Dengan demikian, visioner memberikan arah pada pemimpin untuk membuat fokus yang sudah dicapai untuk dikoreksi manakala tujuan yang dicapai belum maksimal.

Manurut Harefa, visioner adalah suatu ketidakpuasan yang mendalam mengenai realitas faktual masa kini yang dibarengi dengan suatu pandangan yang tajam mengenai kemungkinan menciptakan realitas baru di masa depan, yang secara mendasar lebih baik (Andrias Harefa, 2000: 169). Visioner memiliki penekanan pada ketidakpuasan terhadap realitas faktul masa kini yang mencakup, yaitu 1) adanya pemahaman mengenai suatu konteks, situasi, dan kondisi nyata, kebagaimanaan masa kini; 2) pemahaman itu berdasarkan fakta-fakta empiris dan data-data;3) Pemahaman itu menimbulkan constructive discontent. Artinya suatu bentuk ketidakpuasan yang tidak dirasuki oleh dendam dan sakit hati, tetapi lebih oleh kesadaran terhadap besarnya potensi yang belum teraktualisasikan dengan baik. 


\section{Kepemimpinan Visioner}

Kajian kepemimpinan visioner telah dibahas latar belakang masalah yang menunjukaan bahwa sekolah akan mencapai keunggulan sekolah jika pemimpin sekolah berbasis pada visioner (Dede Rosyada, 2004: 234). Dalam Islam, kepemimpinan telah menempatkan sangat penting sehingga mendapatkan perhatian yang besar. Kedudukan kepemimpinan mempunyai posisi penting sehingga setiap kelompok memiliki pemimpin. Sebagaimana Hadits Nabi Muhammad SAW yang artinya dari Abu Said dari Abu Hurairah bahwa keduanya berkata, Rasulullah bersabda, Apabila tiga orang keluar bepergian, hendaklah mereka menjadikan salah satu sebagai pemimpin (HR. Abu Dawud).

Kepemimpinan mempunyai kekudukan penting tidak hanya dalam ajaran Islam, tapi kajian manajemen intinya terletak dalam kepemimpinan. Kepemimpinan memperhatikan standar visi, misi, dan tujuan sekolah agar tercapai kualitas pendidikan. Ini memberikan tempat dinamika pemimpin berinisiatif di lingkungan sekolah dalam pengembangan lembaga (Made Pidarta, 1995: 81). Penegasan itu tertera pada Surat Al-Baqarah:

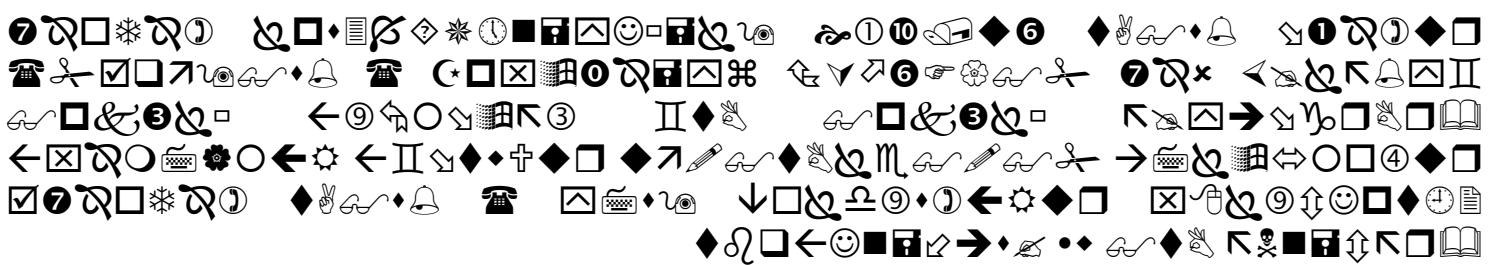

Artinya: "Ingatlah ketika Tuhanmu berfirman kepada Para Malaikat: "Sesungguhnya aku hendak menjadikan seorang khalifah di muka bumi." mereka berkata: "Mengapa Engkau hendak menjadikan (khalifah) di bumi itu orang yang akan membuat kerusakan padanya dan menumpahkan darah, Padahal Kami Senantiasa bertasbih dengan memuji Engkau dan mensucikan Engkau?" Tuhan berfirman: "Sesungguhnya aku mengetahui apa yang tidak kamu ketahui."

Menurut Nanus, pemimpin visioner memiliki empat peran yang harus dijalankan dalam melaksanakan kepemimpinannya, yaitu (Burt Nanus, 2001: 15-18): Pertama, peran penentu arah (direction setter). Peran ini merupakan peran di mana seorang pemimpin menyajikan suatu visi, meyakinkan target untuk suatu organisasi, guna diraih pada masa depan, dan melibatkan orang-orang. Kedua, agen perubahan (agent of change). Agen perubahan merupakan peran penting kedua dari seorang pemimpin visioner. Ketiga, juru bicara (spokesperson). Memperoleh pesan ke luar, dan 
juga berbicara, boleh dikatakan merupakan suatu bagian penting dari memimpikan masa depan suatu organisasi.. Keempat, pelatih (coach). Pemimpin visioner yang efektif harus menjadi pelatih yang baik. Dengan ini berarti bahwa seorang pemimpin harus menggunakan kerjasama kelompok untuk mencapai visi yang dinyatakan.

\section{E. Karakteristik Kepemimpinan Visioner}

Kepemimpinan SD Unggulan Al-Ya'lu Malang dan SD Alam Bilingual Surya Buana Malang mempunyai karakteristik sama dalam mengelola organisasi sekolah.Karakteristik kepemimpinan visioner ke dua lembaga ini adalah jiwa integritas, jiwa adaptasi dan penentu arah (direction setter), jiwa terbuka dan agen perubahan (agent of change), jiwa positif, jiwa disiplin dan jiwa kompetisi. Sebagai dapat dilihat pada gambar berikut. 
Gambar :

Karakteristik kepemimpinan Visioner dibangun melalui Personifikasi Visi dan

Referensi Kepemimpinan

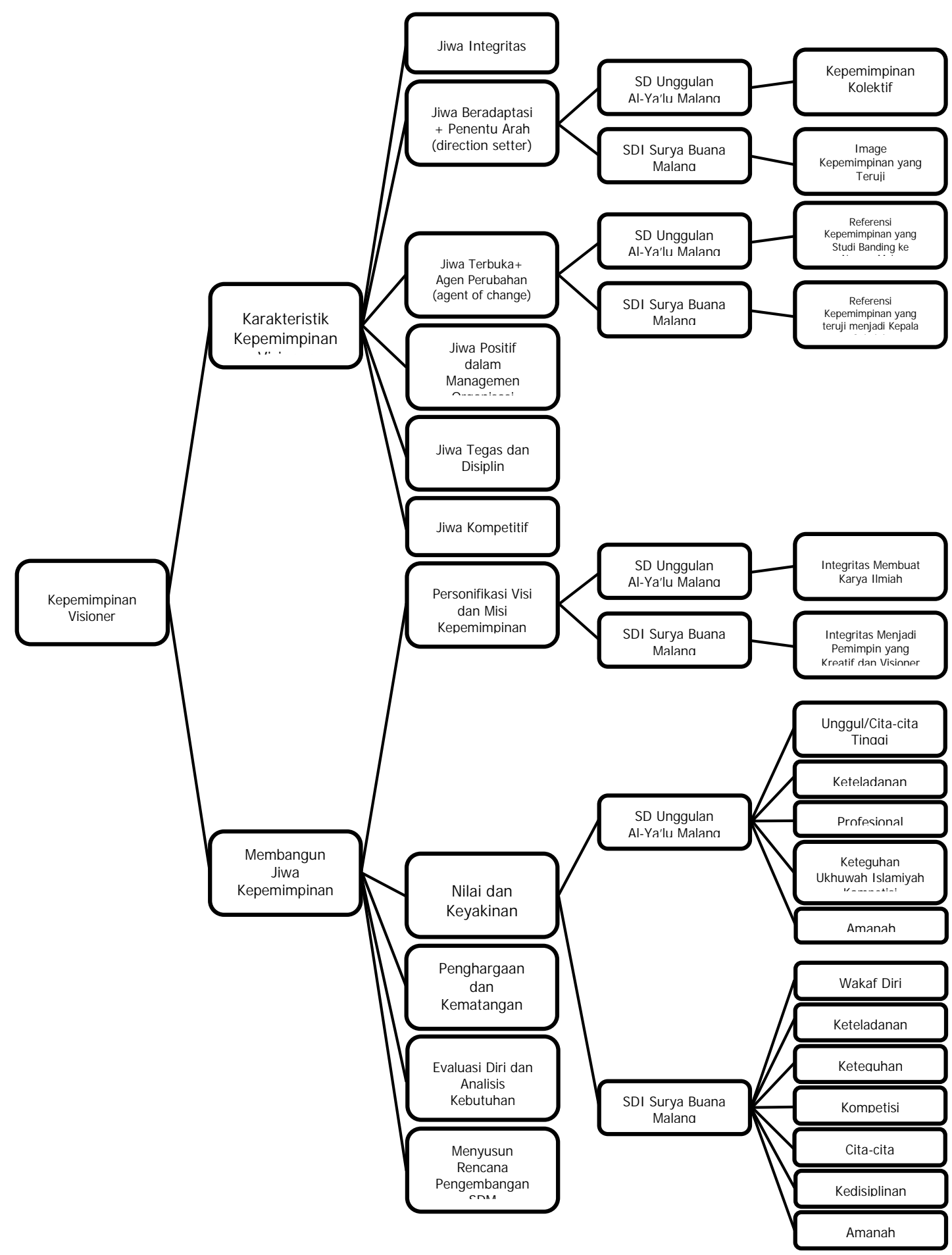

F. Kepemimpinan visioner membangun jiwa visioner pada guru dan pegawai

Kepemimpinan SD Unggulan Al-Ya'lu Malang dan SD Alam Bilingual Surya Buana Malang membangun jiwa visioner pada guru dan pegawai dapat dilihat pada 
gambar di atas. Kepemimpinan visioner lembaga ini adalah personifikasi visi dalam membuat karya-karya ilmiah di SD Unggulan Al-Ya'lu Malang dan personifikasi visi SD Alam Bilingual Surya Buana Malang adalah integritas pengalaman menjadi kepala sekolah.

SD Unggulan AL-Ya'lu Malang mengorganisasi sumber-sumber yang memiliki kekuatan untuk mewujudkan visi sekolah dan menggunakan personifikasi nilai arti Al-Ya'lu yaitu unggul atau di atas, nama itu menjadi nama SD. Filosofi nilai diartikulasi sesuai dengan kebutuhan kepemimpinan yang menghendaki keunggulan menjadi jiwa penggerak warga sekolah. Kepala sekolah mampu mengartikulasikan gagasan besar tersebut ke arah perubahan ke masa depan. Kepala sekolah selaku guru telah menunjukkan prestasi membuat buku ajar tingkat nasional. Hal ini berdampak pada perubahan perilaku warga sekolah memiliki nilai dan jiwa kompetisi pada tingkat lokal maupun tingkat nasional.

Kepala sekolah SD tersebut di atas mempunyai prestasi membuat buku ajar dan mampu menginspirasi warga sekolah. Hal ini didasarkan kepada nilai-nilai keteladanan, profesional, keteguhan, ukhuwah Islamiyah, kompetisi, amanah dan penghargaan. Kepala sekolah beserta wakil kepala sekolah mempersonifikasi visi sekolah dalam bentuk keteladanan sehari-hari. Kemampuan kepala sekolah mempersonifikasi diri bentuk kualitas mengajar, kedisiplinan waktu, dan kreativititas membuat bahan ajar. Personifikasi kepala sekolah telah ditunjukkan dalam menggerakkan warga sekolah melalui intensitas pertemuan internal sekolah dan eksternal sekolah. Internal sekolah berupa aktivitas pembelajaran yang kompetitif agar memicu terwujudnya visi. Sedangkan, eksternal sekolah adalah kepala sekolah berusaha menyalurkan potensi warga sekolah dalam pengembangan guru dan pegawai kantor yang profesional.

Kepala sekolah SDI Alam Bilingual Surya Buana Malang menonjolkan nilai wakah diri untuk menanamkan jiwa visioner kepada warga sekolah. Wakah diri tergambar dari pikiran dan tenaga dicurahkan secara menyeluruh untuk pengembangan lembaga. Nilai tersebut memiliki kekuatan untuk mentransformasikan pola pikir dan sikap menghadapi perubahan sekolah.

Kepala SDI ini menjadi perintis yayasan dan kepala sekolah. Hal berdampak menjiwai dalam menggerakkan organisasi sekolah. Personifikasi nilai terletak pada keteladanan, keteguhan, kompetisi, cita-cita, kedisiplinan dan amanah untuk 
menggerakkan warga sekolah memiliki percaya diri dalam menjalankan setiap profesi. Nilai-nilai tersebut menjadi motor penggerak mewujudkan mimpi-mimpi besar, yaitu, gurunya berstrata pendidikan tinggi, sekolah biligual dan keunggulan sekolah tercapai. Nilai-nilai tersebut dapat dilihat pada table berikut ini.

Tabel : Nilai Dan Kategori Nilai Temuan Penelitian

\begin{tabular}{|l|l|l|l|}
\hline \multicolumn{1}{|c|}{ Lembaga } & \multicolumn{1}{|c|}{ Nilai } & \multicolumn{1}{c|}{ Status } & \multicolumn{1}{c|}{ Sumber } \\
\hline & 1. Unggul/cita-cita tinggi & Terminal & Tuhan/Manusia \\
& 2. Keteladanan & Instrumen & Tuhan/Manusia \\
SD Unggulan Al- & 3. Profesional & Terminal & Manusia \\
Ya'lu Malang & 5. Ukhuwah Islamiyah & Terminal & Manusia \\
& 6. Kompetisi & Terminal & Manusia \\
& 7. Amanah & Terminal & Tuhan/Manusia \\
& 8. Penghargaan & Terminal & Manusia \\
\hline & 1.wakaf diri & Terminal & Manusia \\
\hline \multirow{5}{*}{ SDI Alam Bilingual } & 2.Keteladanan & Terminal & Tuhan/Manusia \\
Surya Buana Malang & 3. Keteguhan & Instrumen & Tuhan/Manusia \\
& 4. Kompetisi & Terminal & Manusia \\
& 5.cita-cita & Terminal & Tuhan/manusia \\
& 6.kedisiplinan & Terminal & Tuhan/manusia \\
& 7.Amanah & Terminal & Manusia \\
\hline
\end{tabular}

\section{G. Perbandingan SD Unggulan Al-Ya'lu Malang dan SDI Alam Bilingual Surya Malang}

Struktur kepemimpinan di kedua sekolah memiliki perbedaan pada aspek tradisi birokratik, sedangkan struktur organisasik berbasis organik dalam menggerakkan organisasi sekolah untuk mewujudkan visi dan tujuan sekolah. Tuntutan SD Unggulan Al-Ya'lu menekankan unggulan yang sudah terlembaga, jika SDI Alam Bilingual Surya Buana Malang menekankan pada kreativitas warga sekolah.

Alat kontrol dan profil pemimpin memunyai perbedaan yang tajam. Budaya program kompetisi dan kontrak kerja merupakan dasar untuk mengukur keberhasila visi sekolah di SD Unggulan Al-Ya'lu Malang, sedangkan di SDI Alam Bilingual Surya Buana Malang menggunakan alat kontrol budaya kompetisi yang sudah dibangun sejak berdirinya lembaga ini. Profil pemimpin SD ini adalah kontributor pendiri yayasan dan prestasi menjadi kepala sekolah. Ia mewakafkan diri menjadi perintis sekolah yang berkarakter dan berprestasi. Salah satu bukti adalah sekolah mendapatkan penghargaan dari UIN Award 2008 dari Prof. Dr. H. Imam Suprayogo, 
Rektor UIN Maliki Malang. Sedangkan, kepala SD Unggulan Al-Ya'lu Malang memiliki dedikasi tinggi dan guru yang profesional dan berprestasi yang menyebabkan dapat kepercayaan menjadi kepala sekolah.

Sistem kepemimpinan dan personifikasi pemimpin dua lembaga ini mempunyai pengaruh kuat terhadap penjiwaan sekolah yang dapat mengartikulasi visi sekolah dan dapat menginspirasi warga sekolah untuk mewujudkan visi. Sistem kepemimpinan SD Unggulan Al-Ya'lu Malang adalah personil pemimpin sekolah dan personil pendiri yayasan memimpin secara kolektif. Pendiri yayasan terdiri-dari para pegawai VEDC Arjosari Malang. Dan aspek personifikasi pemimpin meletakkan keteladanan membuat karya-karya ilmiah dan kedisiplinan. SDI Alam Bilingual Surya Buana Malang adalah kekuatan kepala sekolah merupakan penggerak utama perubahan lembaga dan personifikasi pemimpin adalah amanah dan keteguhan mengelola potensi sekolah yang merupakan kekuatan yang mampu mewujudkan impian-impian sekolah yang unggul dan inovasi. Pengalaman hidup menjadi kepala sekolah yang selalu mewakahkan diri demi kemajuan lembaga. Hal ini mempengaruhi keteguhan seorang pemimpin dalam mengelola sekolah sebagai investasi yang tidak akan rugi.

Referensi kepemimpinan dan penentu arah (direnction setter) mempengaruhi kematangan dan ketahanan mengelola lembaga yang mempunyai karakteristik yang kuat dalam bidang unggulan sekolah. Referensi kepemimpinan SD Unggulan Al-Ya'lu Malang adalah hasil studi banding ke luar negeri yang menunjukkan perubahan yang sesuai dengan visi sekolah pada bidang kemajuannya dan aspek penentu arah adalah kepala sekolah dan yayasan merupakan penggerak sistem menuju arah sekolah ke depan. Sedangkan SDI Alam Bilingual Surya Buana Malang mempunyai referensi kepemimpinan pengalaman panjang menjadi kepala madrasah dan pengalaman merubah madrasah pinggiran menjadi kelas menengah atas. SDI ini pada aspek penentu arah adalah image kepemimpinan yang teruji untuk menggerakkan arah sekolah ke arah depan dan kemajuan lembaga. 
Gambar: Perbandingan kepemimpinan SD Unggulan Al-Ya'lu Malang dan SD Alam Bilingual Surya Buana Malang



\section{H. Penutup}

Berdasarkan fokus penelitian,maka hasil penelitian ini dapat disimpulkan sebagai berikut ini:

1. Karakteristik kepemimpinan visioner pada SD Unggulan Al-Ya'lu Malang dan pada SDI Alam Bilingual Surya Buana Malang dapat dipresentasikan sebagai berikut:

a. Kepemimpinan visioner menggambarkan organisasi sekolah lebih nampak sebagai organisasi organik dari pada organisasi mekanik. 
b. Jiwa visioner pemimpin tergambar pada nama sekolah yang inklusif dan jiwa mewakahkan diri secara profesional yang dapat mendorong untuk memfokuskan tercapainya visi sekolah.

c. Agen pembaharuan merupakan karakteristik kepemimpinan visioner yang menggerakkan seluruh warga sekolah mengartikulasi visi sekolah.

d. Penentu arah dapat mengukur standar-standar prestasi atau unggulan sekolahdan mencerminkan cita-cita yang tinggi. Visi menggambarkan organisasi sebagai komunitas yang bertanggung jawab, yang memiliki integritas yang kuat dan mengangkat moral setiap orang di dalamnya. Karakteristik kepemimpinan visioner mengelola standar-standar harapan yang dapat diwujudkan dalam jangka pendek dan mengelola standar-standar harapan yang dapat diwujudkan dalam jangka panjang di sekolah.

e. Karakteristik jiwa visioner pemimpin telah ditunjukkan dalam mengelola organisasi sekolah secara terus-menerus tanpa berhenti menemukan sesuatu yang unggul dari sudah unggul.

2. Kepala sekolah membangun jiwa visioner guru dan pegawai kantor pada SD Unggulan Al-Ya'lu Malang dan pada SDI Alam Bilingual Surya Buana Malang dapat dipresentasikan sebagai berikut:

a. Kepala sekolah mampu menunjukkan personifikasi visi terhadap harapan sekolah. Personifikasi visi sekolah adalah kemampuan dasar menggerakkan warga sekolah untuk mengartikulasi visi sesuai dengan harapan sekolah.

b. Kepala sekolah mendasari pemaknaan visi kepemimpinan melalui cara nilai-nilai transendental ditanamkan kepada jiwa setiap warga sekolah. Penanaman nilai-nilai itu melalui kontrak kerja pengabdian, rapat rutin sekolah, kegiatan keagamaan di sekolah dan keteladanan pemimpin sekolah.

c. Kepala sekolah menyakini bahwa setiap warga sekolah memiliki keunggulan potensi dan kekurangan potensi. Keunggulan sekolah dapat dikelola jika setiap warga sekolah mendapatkan kesempatan berkompetisi. Kompetisi adalah wadah mengukur kreativitas pendidik dan pegawai kantor. Kompetisi dapat mendorong perubahan dan 
pengembangan sekolah manakala ditunjang kematangan emosi. Kematangan emosi terukur dan teruji dibutuhkan konsistensi jiwa kompetisi.

d. Kepala sekolah membangun lingkungan sekolah secara kompetitif dan secara harmonis. Hal ini untuk menunjang kemampuan warga sekolah dalam menstimulus lingkungan yang saling bekerja sama untuk mencapai keunggulan sekolah.

3. Perbandingan SD Unggulan Al-Ya'lu Malang dan pada SDI Alam Bilingual Surya Buana Malang dapat dipresentasikan sebagai berikut:

a. Kepemimpinan visioner di SD Unggulan Al-Ya'lu Malang lebih nampak kepemimpinan kolektif yang menonjol karena pengurus yayasan, kepala sekolah, wakil kepala sekolah dan konsultan pendidikan menyatu dalam menggerakkan organisasi sekolah. Sedangkan, SDI Alam Bilingual lebih menonjol kepemimpinan individu karena kepala sekolah dan pengurus yayasan adalah kepala sekolah yang sekaligus pendiri lembaga ini yang menyebabkan organisasi sekolah bergeraknya menyatu.

b. Personifikasi kepemimpinan sekolah SD Unggulan Al-Ya'lu Malang didasarkan nilai-nilai unggulan dari perencanaan pendiri yayasan dan pengamalan menjadi guru berprestasi dan SDI Alam Bilingual Surya Buana Malang didasarkan pada rekam jejak pengalaman mengelola madrasah pinggiran menjadi sekolah yang unggul.

c. Kepemimpinan sekolah menggerakan budaya unggul didasarkan tradisi kompetisi dan kontrak kerja di SD Unggulan Al-Ya'lu Malang dan pembiasan kreatif dan budaya kompetisi di SDI Alam Bilingual Surya Buana Malang.

d. Persamaan yang dibangun adalah memiliki jiwa penggerak perubahan yang didasarkan oleh nilai-nilai dan keyakinan yang dipegang oleh kedua pemimpin.

Berdasarkan dokus penelitian dan hasil penelitian yang sudah dipaparkan diatas, berikut Implikasi Teori dari penelitian tersebut:

1. Penelitian ini secara teori menemukan konsep tentang kepemimpinan visioner dalam menggerakkan organisasi sekolah yang menunjukkan 
keunggulan sesuai dengan visi sekolah. Konsep karakteristik kepemimpinan visioner memperkuat pemikiran John Adair, Burt Nanus, Stephen Robbins. Pendapatnya adalah jiwa adaptasi dan penentu arah (direction setter), jiwa integritas, agen perubahan dan pola pikir positif. Sedangkan, temuan penelitian jiwa terbuka, tradisi kompetisi, dan wakah diri adalah karakteristik yang unik yang tidak dimiliki selain kepemimpinan visioner. Hasil penelitian ini memperkaya hasanah studi manajemen pendidikan Islam

2. Pemimpin yang mempunyai integritas adalah orang yang memiliki watak, karakter, dan kepribadian yang utuh sejati, tampil apa adanya tetapi tetap cantik lahir dan batin. Sebagai contoh, sifat-sifat Rasulullah Saw diantaranya, siddiq (trust), amanah (responsibility dan accountability), fathanah (smart) dan tabligh (openly) yang pada gilirannya terakumulasi membentuk sifat al-amin (terpercaya) adalah menggambarkan pribadi yang memiliki integritas. Dalam bahasa agama, integritas adalah akhlakul karimah. Nilai-nilai kenabian tersebut menjadi sumber rujukan memahami kepemimpinan. Jadi, penelitian ini mempertajam penelitian Tobroni dan mendukung karakteristik kepemimpinan visioner yang merujuk nilai-nilai transendental.

3. Karakteristik kepemimpinan visioner merupakan kesinambungan dari kepemimpinan transformasional, namun kepemimpian ini lebih memfokuskan transformasional gagasan visi sekolah yang didasari oleh nilai-nilai dan jiwa pemimpin sekolah. Penelitian juga mengembangan teori kepemimpinan transformasional Disertasi Tobroni. Sebagaimana juga pemikiran Rhenald Kasali bahwa kepemimpinan visioner menekankan perubahan diri menuju perubahan secara kelembagaan berdasarkan.

4. Hasil penelitian memberikan kontribusi terhadap pengembangan secara teoretis tentang Manajemen Pendidikan Islam (MPI) terutama ranah leadership yang berbasis ide dan nilai, karena penelitian ini berhubungan penggerak utama perubahan adalah bukan materi, namun nilai dan pemahaman kejiwaan seorang pemimpin sekolah. 
5. Temuan penelitian ini mempertegas teori-teori Gary Yukl, Syafii Antonio, dan Raihani bahwa pendorong kepemimpinan visioner yang menekankan nilai transendental bukan nilai yang bersifat materi.

\section{Daftar Pustaka}

Antonio, Syafii Muhammad. 2007. Muhammad SAW Super Leader dan Super Manager. Jakarta: Pro LM Centre.

Bass, Bernard M. (1981). Stogdill's Handbook of Leadership: A Survey of Theory and Research. New York: The Free Press, A Division of Macmillan Publishing Co., Inc.

Beach, Lea Roy. (1993). Making the Right Decision: Organizational Culture, Vision, and Planning, Prentice-Hall, Inc. Engliwaad Cliffs.

Bennis, W. dan R. Townsend. (1995). Reinventing Leadership. New York: William Morrow and Company. Inc.

Bennis, Warren. (1994). On Becoming a Leader. New York: Addison Wesley.

Cohen, William A. (1990). The Art of the Leader. Simon dan Schuster.

Harefa, Andrias. (2000). Menjadi manusia Pembelajar. Jakarta: Kompas.

Kamus Besar Bahasa Indonesia. (2005). Jakarta: Balai Pustaka.

Kasali, Rhenald. (2007). Re-code Your Change DNA (Membebaskan Belenggu-belenggu untuk meraih keberanian dan keberhasilan dalam pembaruan). Jakarta: PT Gramedia Pustaka Utama, Jakarta.

L. Hughes, Richard dan Robert C. Ginrett, Gordon J. Curphy. (2002). Leadership (Enhancing the Experience). , New York: The Mc Graw-Hill of the Americas.

Nanus, Burt. (1989). The Leader's Edge: The Seven Keys to Leadership in a Turbulent World. New York: Contemporary Books.

Nanus, Burt. (2001). Visionary, Leadership:creating a compelling sense of direction for your organization. terj. Frederik Ruma. Jakarta: PT Prenhallindo.

P. Kotter. John. (1994). Leadership-dialog with 100 Top Leader. The Leadership Press.

Rosyada, Dede. (2004). Paradigma Pendidikan Demokratis Sebuah Model Pelibatan Masyarakat dalam Penyelenggaraan Pendidikan. Jakarta: Prenada Media.

Robbins, Stephen. (1996). Organizational Behavior: Concept, Controversies, and Applications. Prentice-Hall International, Inc., Upper Saddle River New Jersey.

Sallis, Edward. (1993). Total Quality Management in Education, New Jersey: Prentice-Hal. Inc.

Suryadi, Ace dan H.A.R. Tilaar. (1993). Analisa Kebijakan Pendidikan: Suatu Pengantar. Bandung: Remaja Rosdakarya.

Steers, R.M., G.R. Ungson, dan R.T. Mowday. (1985). Managing Effective Organizations. Kent Publishing Company: A Division of Wadsworth,Inc, Boston Massachusetts.

Tilaar, H.A.R. (1997). Pengembangan Sumber Daya Manusia dalam Era Globalisasi: Visi, Misi, dan Program Aksi Pendidikan dan Pelatihan Menuju 2020. Jakarta: Grasindo.

Tobroni. The Spiritual Leadership: Pengefektifkan Organisasi Noble Industry Melalui PrinsipPrinsip Spiritual Etis. Malang: UMM Press.

Terry, Robert W. (2002). Kepemimpinan Autentik. (Alih bahasa: Hari Suminto). Batam: Interaksara.

Yukl, Gary. (2002). Leadership in Organizations, Prentice-Hall International, Inc, New Jersey, 2002, h. 3 
Muh. Hambali- Kepemimpinan Visioner (Studi Multi Kasus di SD Unggulan Al-Ya'la Malang dan SD I Alam Bilingual Surya Buana Malang)

Yukl, Gary. (1981). Leadership in Organizations. New Jersey: Prentice-Hall International. 